\title{
E-Commerce Performance. Shopping Cart Key Performance Indicators
}

\author{
Mihaela I. MUNTEAN ${ }^{1}$, Diana TÂRNĂVEANU ${ }^{1}$, Alina Raluca ION ${ }^{2}$ \\ ${ }^{1}$ West University of Timisoara, Timişoara, România \\ ${ }^{2}$ InSites Consulting, Timişoara, România \\ mihaela.muntean@e-uvt.ro,diana.tarnaveanu@e-uvt.ro, alina.ion88@gmail.com
}

In an e-commerce performance framework is important to identify the key performance indicators that measure success and together provide the greatest context into the business performance. Shopping carts are an essential part of ecommerce, a minimal set of key performance indicators being the subject of our debate. The theoretical approach is sustained by a case study, an e-shop implemented using PHP and MySQL, for simulating main business processes within the considered performance framework. Our approach opens a perspective for future research using additional indicators in order to properly evaluate the global performance of any e-shop.

Keywords: Performance, E-Commerce, KPI, Shopping Cart

\section{Introduction}

According to Adrian Brudan, "Key Performance Indicators (KPIs) help quantify the achievement of a goal, providing visibility towards employees, teams, departments and an organization's performance, enabling decision makers to take action to achieve the desired goal" [1]. When choosing the relevant KPIs for a company we have to take into account the strategic objectives (turnover, profit, costs - intensive or extensive development), the time frame (long term or immediate profit), the company profile (services, manufacturing, distribution), current situation on the growth curve of the company's development (growth, maturity, decline) and the company's management style.

"The indicators should be grounded to the dynamic and typology of a company and require a lot of discernment related to monitoring and controlling activities."[2].

"KPIs are a set of measurements or metrics used for defining and evaluating certain aspects of e-commerce" [3]. KPIs should illustrate a company's objectives from the top to the lowest level, expressed in traceable operational indicators at department/function/employee levels.

More and more companies realize the importance of metrics monitoring on short term, medium or long-term objectives. Often, some business processes don't return the expected profit. Monitoring specific business process indicators leads to observing the changes at the level of various processes themselves and detecting the causes that led to those changes. "Key performance indicators are becoming common in large corporations as a way to measure and monitor the success of key activities. But they can also play an important role in any sized e-commerce business" [4]. KPIs are important because they can help improve the performance of a website. E-commerce KPIs are numerous, covering all aspects of the e-commerce transactions. Best practices recommend to focus on KPIs frameworks that are grouping together related KPIs. In this general context shopping cart KPIs are subject of the debate.

\section{Key Performance Indicators}

KPIs represent a set of measures that focus on those critical organizational performance aspects that are most important to insure the present and future success of the company. "Once an organization has analyzed its mission, identified all its stakeholders, and defined its goals, it needs a way to measure progress toward those goals. Key Performance Indicators are those measurements." [4].

The selected indicators should reflect a company's objectives, they should be the company's success key and they should be quantified. Usually, KPIs are considered on long 
term. Their definition and the way they are measured doesn't change, but the objectives of a particular indicator can change, in order to reflect the changes in the organization's objectives.

As Thomson said [5], "...when the thing that we are interested in can be quantified, expressed in a numeric form, then we know something about it"; the performance indicators have to be quantifiable in order to reflect a company's state related to specific objectives.

Defining key performance indicators according to the company profile and objectives implies the following key steps [6]:
- Business processes should be clearly defined;

- The requirements of the business processes should be known;

- There has to be a balance between qualitative and quantitative results and a comparison with the initial goals;

- Optimization processes and necessary resources should be investigated, in order to achieve goals and to add value to the company.

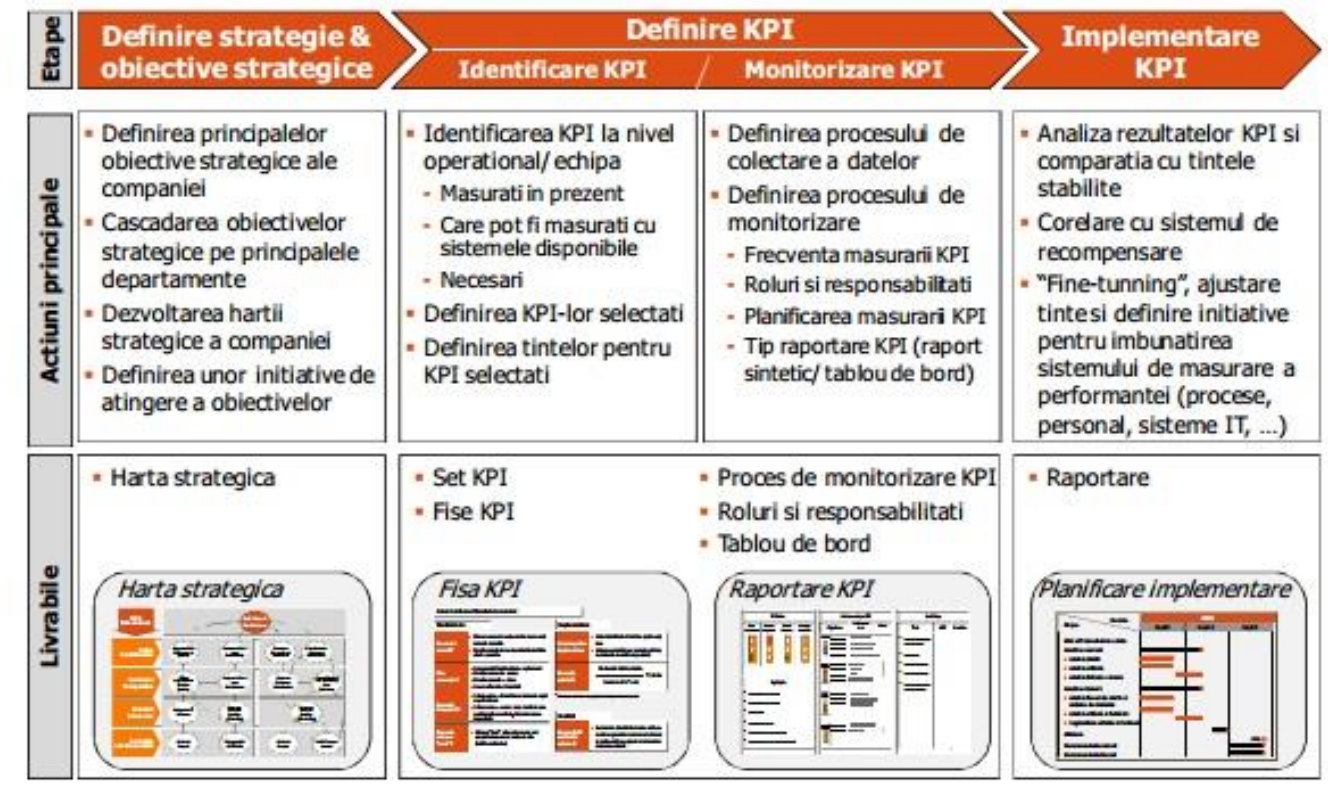

Fig. 1. Setting and defining KPIs [6]

Figure 1 depicts in detail the steps that occur in key performance indicators implementing process

Through monitoring the right indicators, a valuable perspective of the business performance is achieved and the degree of the strategic awareness that is needed to make the best decisions at the right time is increased.

Key performance indicators should be carefully introduced. It is important to establish what makes an indicator a key one, what type of information should be provided for each KPIs and how KPIs can be presented in order to provide efficient business reporting.
In order to determine which information should be reported with the help of indicators, the following principles should be considered:

- The analyses should be balanced and comprehensive;

- The analyses should reflect the business in a correct way;

- The analyses should provide the necessary information for understanding de development, performance and the position of the company on the market.

Best practices in the field of performance management recommend a number between 4 to 10 key performance indicators essential to any company. According to a study provided by Ensight Management Consulting [6], more 
and more companies try to understand the concept of KPI and synchronize it with their objectives. Approximately $81 \%$ of Romanian companies use KPIs based analysis, and the trend is growing. Among the reasons for adopting this type of analysis are monitoring the achievement of strategic objectives, reporting results and transparency, and performance evaluations for departments and individuals.

\section{Online shops KPIs}

Key performance indicators are milestones on the road to successes of any company, regardless of its field of activity. The online retail industry is well equipped for analyzing key performance indicators. E-commence entrepreneurs can identify the progress of sales or improve its customer oriented services through monitoring KPIs.

The first step in selecting the right indicators is setting the objectives and understanding business areas that impact those objectives. There should be different indicators for each goal, no matter if it is regarding the sales increase, optimizing the marketing process or improving customer oriented services. Analyzing those factors, the following indicators can be chosen:

- Sales increase;

- Increasing website's traffic;

- Reducing the calls related to Customer Service.

Each e-shop has the main objective to increase sales, but most of the times this objective implies a series of actions related to the number of active visitors, the cost of the products sold, competitive prices and even the shopping cart's dropout rate.

Shopping cart's dropout rate (Rata de abandon al coșului de cumpărături - RA)

After [8] "Instead of reflecting how many visitors became clients, this metric reflects how many visitors almost became clients, abandoning the purchasing process...". This indicator reflects how frequent a visitor adds products to the cart but because of different reasons fails to complete the purchasing process.
The following formula is used to calculate RA:

$$
\mathrm{RA}=(1-\mathrm{NA} / \mathrm{NV}) * 100
$$

RA - Abandon rate (Rata de abandon)

NA - Number of completed transactions

(Numărul de achiziţii complete)

$\mathrm{NV}$ - Number of visitors that added products to the cart (Numărul de vizitatori care au adăugat produse în coşul de cumpărături)

The result reflects the percentage of visitors that added products to the shopping cart and decided at the last minute not to purchase them. This indicator arises questions related to its value - if its value is high, maybe the shipping costs are too high, the delivery time is too long, the prices are not the expected ones, etc. The response of those questions should generate actions that optimize the processes related to this indicator.

Average revenue per visitor (Venitul mediu pe vizitator - VM)

This indicator "...through a single metric, provides an overview on online sales that describes the health of a mature e-shop." [9].

The following formula is used to calculate VM:

$$
\mathrm{VM}=\mathrm{VT} / \mathrm{NV}
$$

$\mathrm{VM}$ - Average revenue per visitor

VT - Total revenue

$\mathrm{NV}$ - Number of visitors

It is obvious that the larger the VM is, the healthier the business is. The obvious strategy that can be used to improve the value of this indicator is to attract more valuable customers.

Orders conversion rate (Rata de conversie a comenzilor $-R C$ )

$\mathrm{RC}$ "...is designed to help anybody who sells online products to understand the rate on which they receive orders during visits on the website." [9].

The orders conversion rate reflects the number 
of orders related to the number of visitors, ideally the number of orders should be higher than the number of visitors, meaning that there are loyal customers that return and buy more than once. But most times, the rate is somewhere between 2 and 5 percent, which means that between 95 and 98 percent out of total visitors didn't return to buy products from the website.

$\mathrm{RC}$ is calculated based on the following formula:

$$
\mathrm{RC}=\mathrm{NC} / \mathrm{NV}
$$

$\mathrm{RC}$ - Conversion rate

$\mathrm{NC}$ - Total number of orders

$\mathrm{NV}$ - Number of visitors

In an online business there will always be a pretty high segment of visitors that visit the website without the intention of purchasing. The strategy of raising the conversion rate is to optimize the marketing process so that the website should attract more visitors that will place orders. The start page can be optimized so that the visitors can quickly find the products they need and go through the payment process without any impediment.

Average products in an order (Numărul mediu de produse pe o comandă - NMP)

This indicator reflects the number of products in each shopping cart purchased in a single order.

The following formula is used to calculate NMP:

$$
\mathrm{NMP}=\mathrm{NP} / \mathrm{NC}
$$

NMP - Average number of products in an order

$\mathrm{NP}$ - Total number of products ordered

$\mathrm{NC}$ - Total number of completed orders
It is quite difficult to raise the value of this indicator when a visitor usually buys only one product. This indicator is highly related to the product and the purchased quantity.

Average value of an order (Valoarea medie a unei comenzi - VMC)

A close look on this indicator's value can illustrate the customer's behavior and will open opportunities of ,up-sell” and ,cross-sell” [8]. „Up-selling is a selling technique that addresses raising the selling profitability by guiding the customer to buy more expensive or newer versions of products or services. Cross-selling proposes selling to an existing customer additional products that are strongly linked to the main product, like accessories or updates" [10].

The following formula is used to calculate VMC:

$$
\mathrm{VMC}=\mathrm{VC} / \mathrm{NC}
$$

VMC - Average value of an order

$\mathrm{VC}$ - Orders value

$\mathrm{NC}$ - Number of orders

Any changes in the value of the indicator should be diagnosed, monitoring the changes in the purchasing process and in the marketing acquisition program.

\section{Our Proposal}

\subsection{The e-shop}

The conceptual schema was implemented in PHP and MySQL. Enough data was recorded so that the analysis of the key performance indicators would be relevant. The data used when calculating the indicators was loaded from operations at the website's database level. 


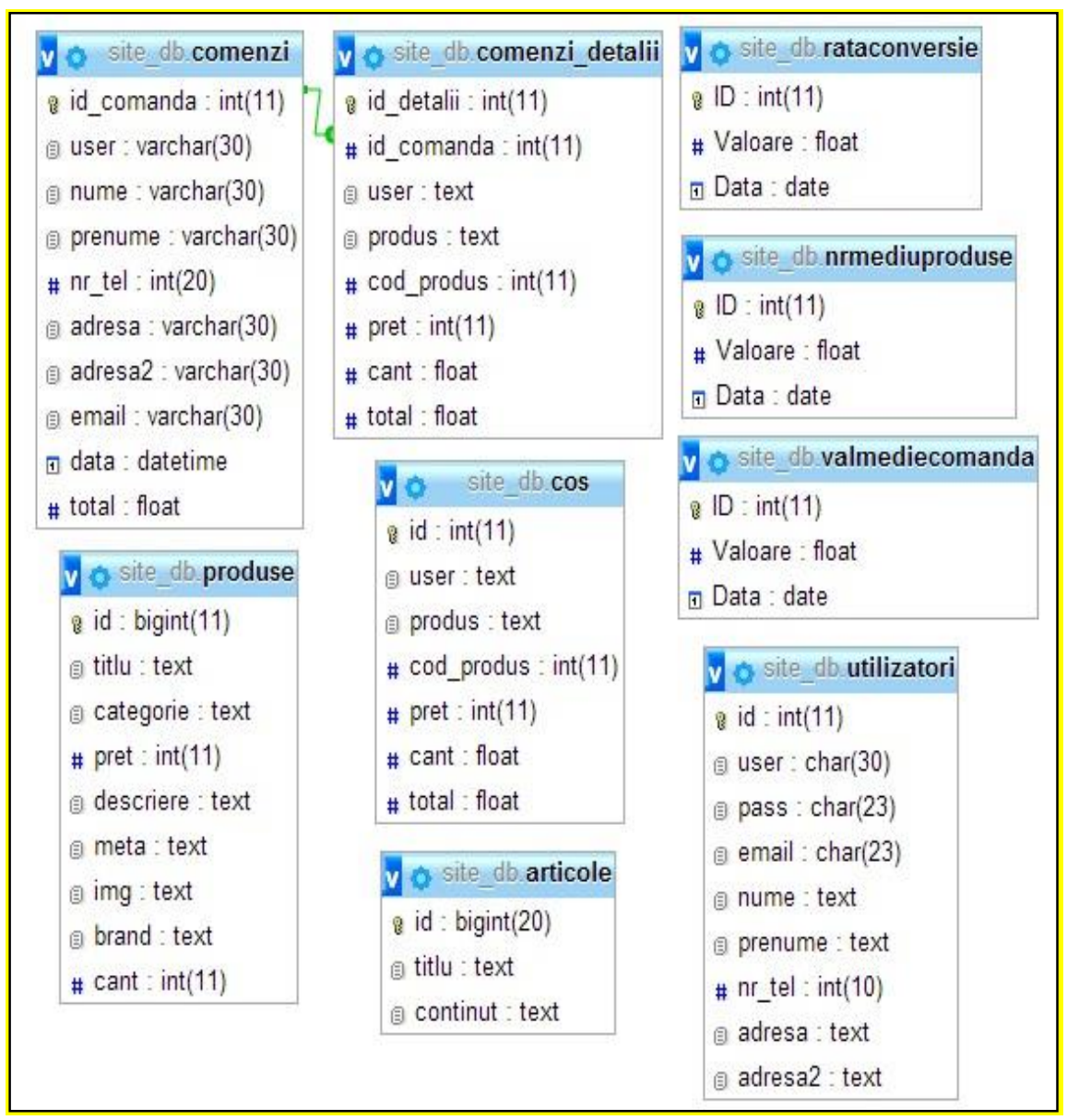

Fig. 2. Conceptual schema of the database

For monitoring the KPIs, we propose an eshop with basic functionalities. The website is hosted on a local Apache server, and is built using PHP, HTML and CSS. The e-shop uses data from a MySQL database (Figure 2) and is named "ElectroShop". The e-shop's field of activity is selling home appliances, delivered through postal service and paid in cash at delivery. The e-shop offers different services, depending on the user type. A visitor can only purchase products after enrolling to this website. The administrator cannot buy products, but he can edit or delete any information on the website. He can also monitor the key performance indicators (Figure 3).

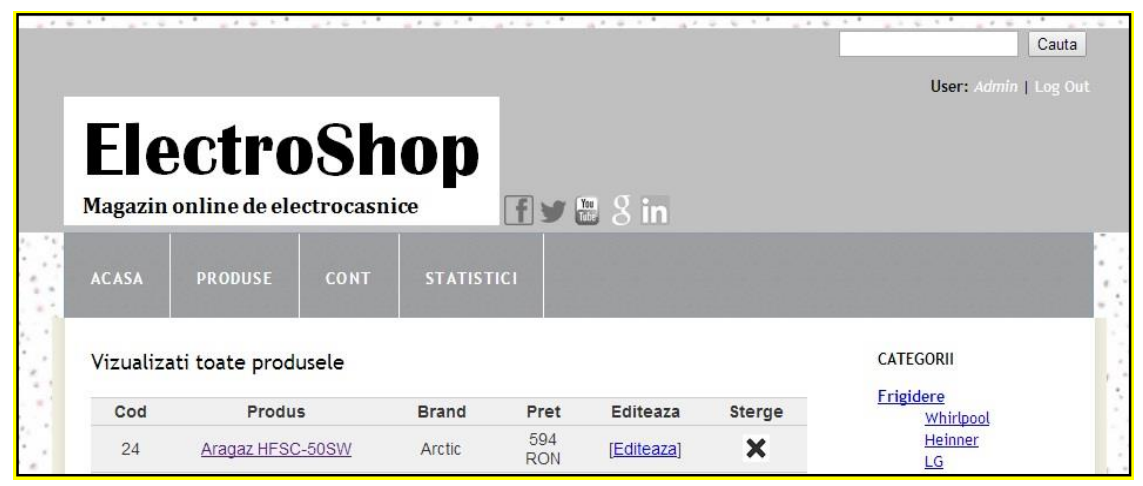

Fig. 3. Administrator menu

The products are divided into categories, so they can be found easily by customers. An enrolled visitor has access to his account data 
and can make any change to it. Users have access to the Contact page where they can send e-mails regarding any problem. This application has basic functionalities that are sufficient for calculating and monitoring the proposed indicators.

\subsection{Shopping cart}

The shopping cart is the most important part of an e-shop. The goal of an e-shop is to sell, this action being implemented through the shopping cart. In this application, data from the shopping cart is recorded into a table called cos from the database. When the purchasing process is completed (Figure 4) the data from the shopping cart is sent into comenzi and comenzi_detalii tables.

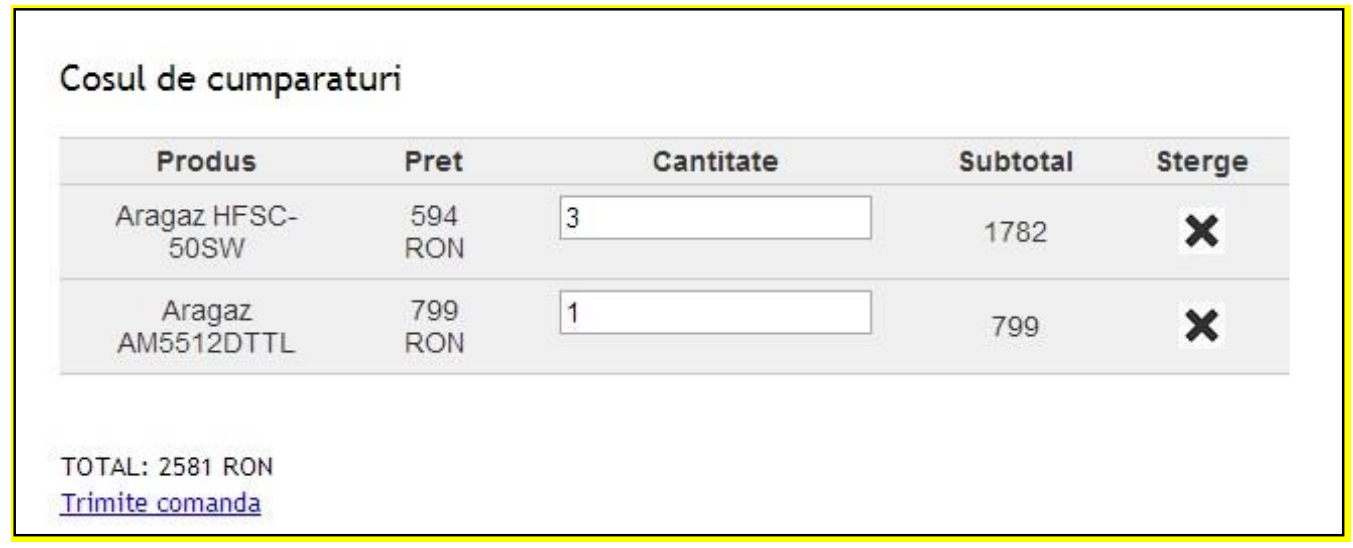

Fig. 4. The shopping cart

\subsection{Implementing the KPIs}

For monitoring business processes (main objective: monitoring sales in order to increase them), three of the most important e-commerce specific indicators were selected:

- RC - Orders conversion rate;
- NMP - Average products in an order;

- VMC - Average value of an order.

Only the Administrator has access to these indicators, using the menu option Statistici (Figure 5).

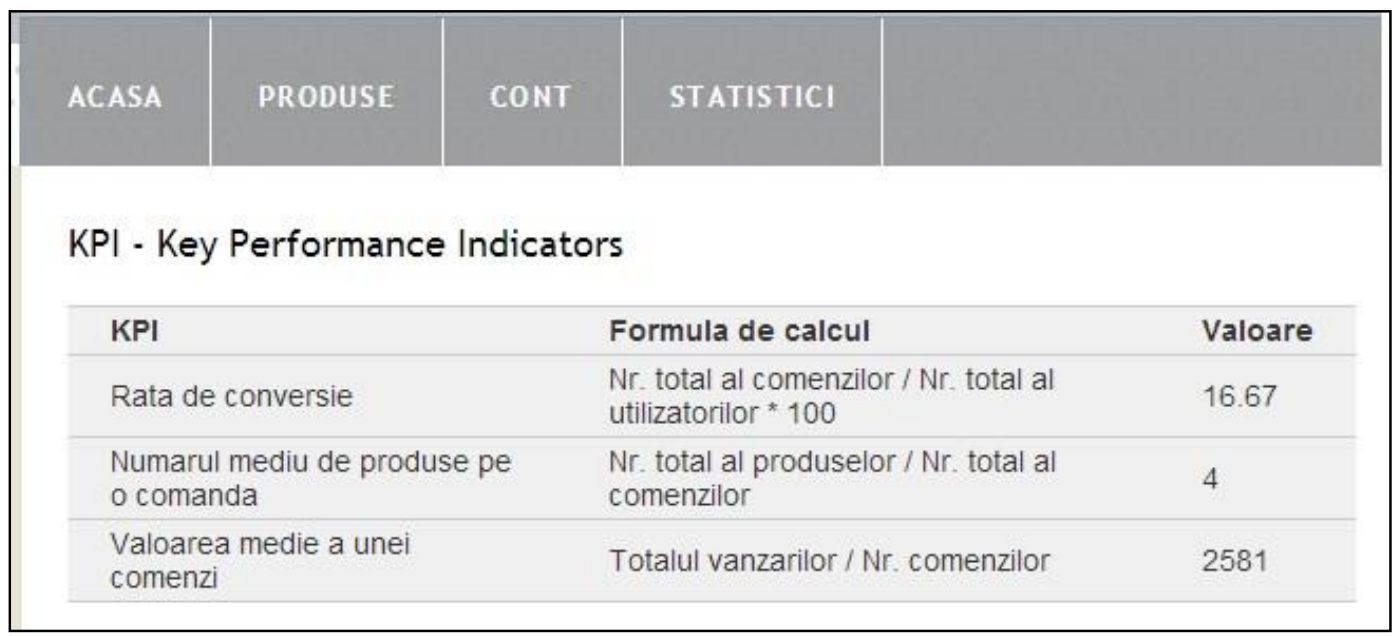

Fig. 5. Key performance indicators

The code that performs the indicators calculation is presented next: 


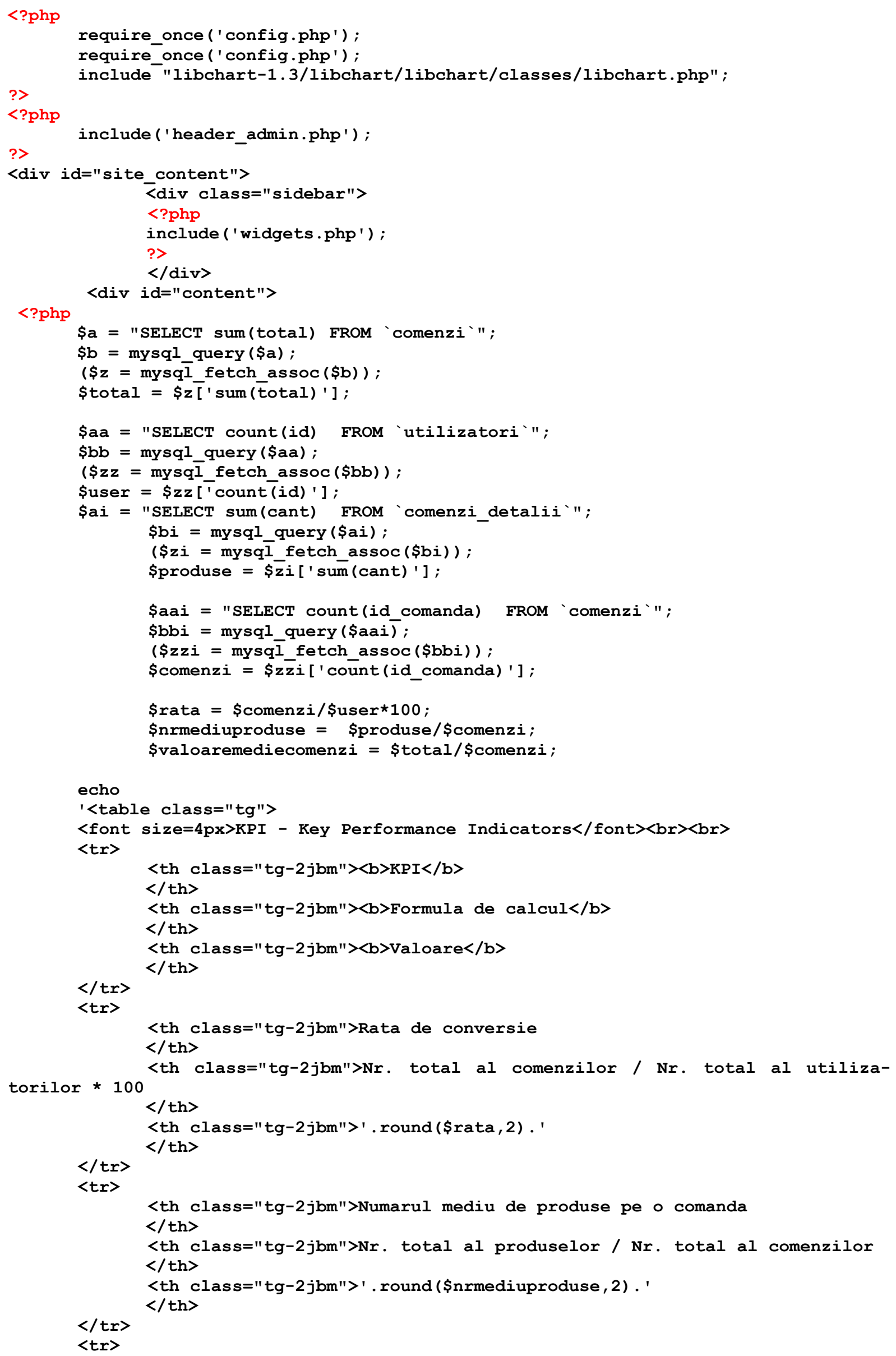




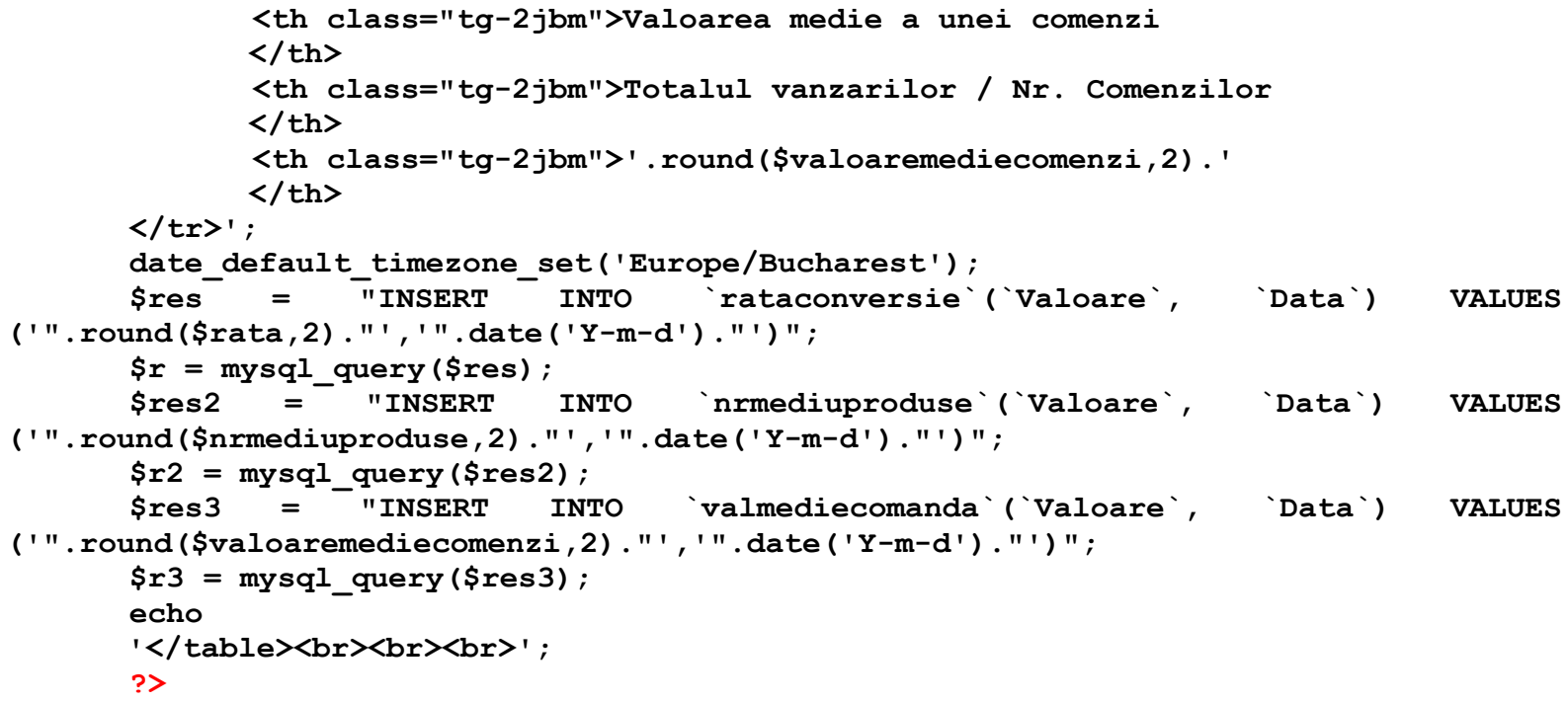

\section{Results}

The goal of building the e-shop and implementing KPIs is to monitor their values so that the position of the company can be evaluated. In order to determine the key performance indicators' evolution they can be displayed as charts. Each indicator is optimized by maximization, without having a fixed optimum value.

When implementing KPIs, the following steps are followed:

Step 1. Enrolling of the visitor in order to purchase products;
Step 2. Choosing the products that will be purchased and placing them in the shopping cart; Step 3. Completing the order;

Step 4. The Administrator logs in and monitors the indicators' evolution:

- Orders conversion rate (Rata de conversie) $\mathrm{RC}=28.57 \%$ (Figure 6)

- Average products in an order (Numărul mediu de produse pe o comandă) NMP = 5 (Figure 7)

- Average value of an order (Valoarea medie a unei comenzi) $\mathrm{VMC}=3638$ (Figure 8).

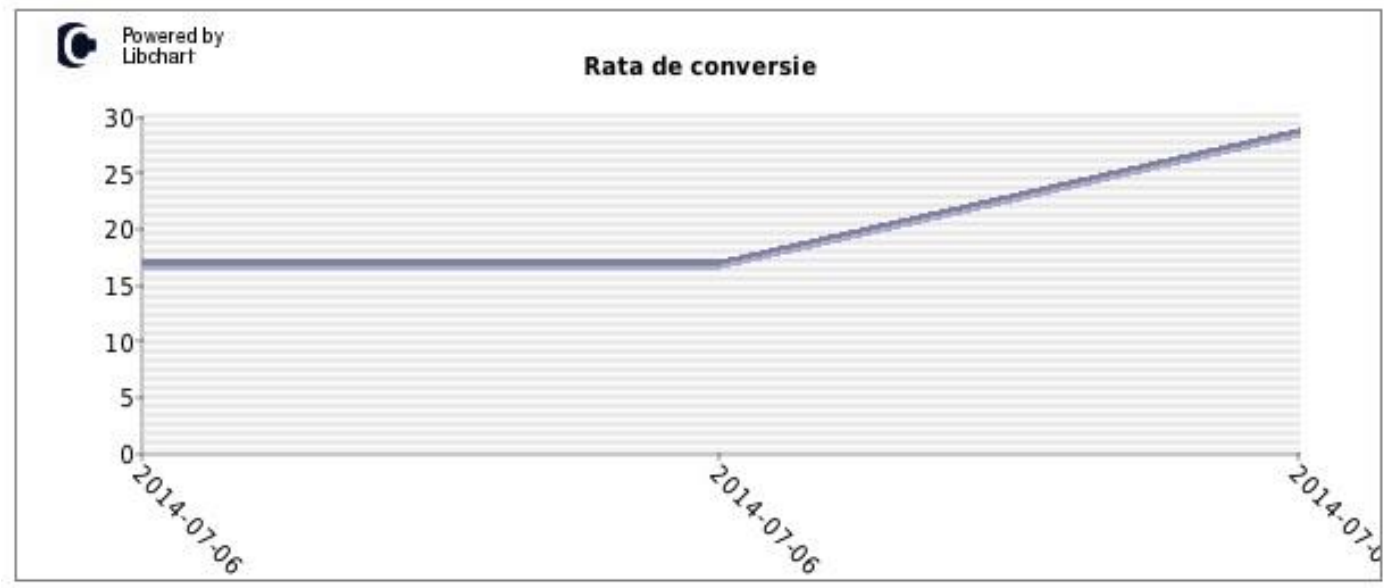

Fig. 6. Orders conversion rate (Rata de conversie) 


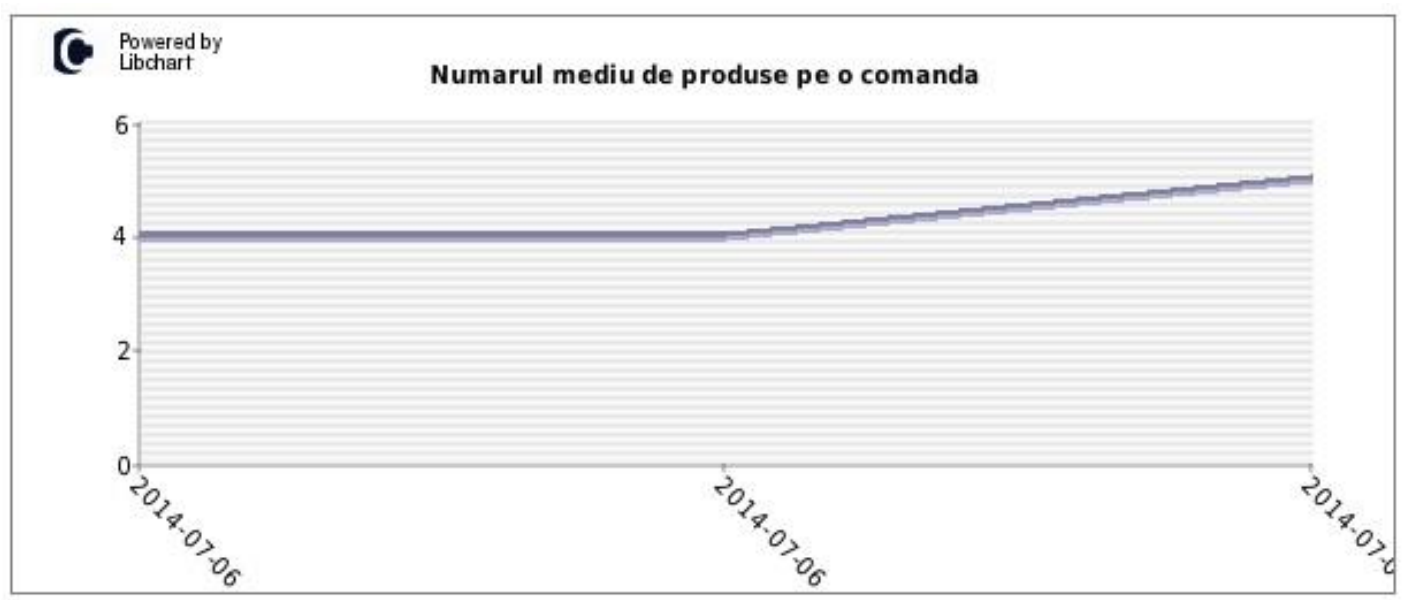

Fig. 7. Average products in an order (Numărul mediu de produse pe o comandă)

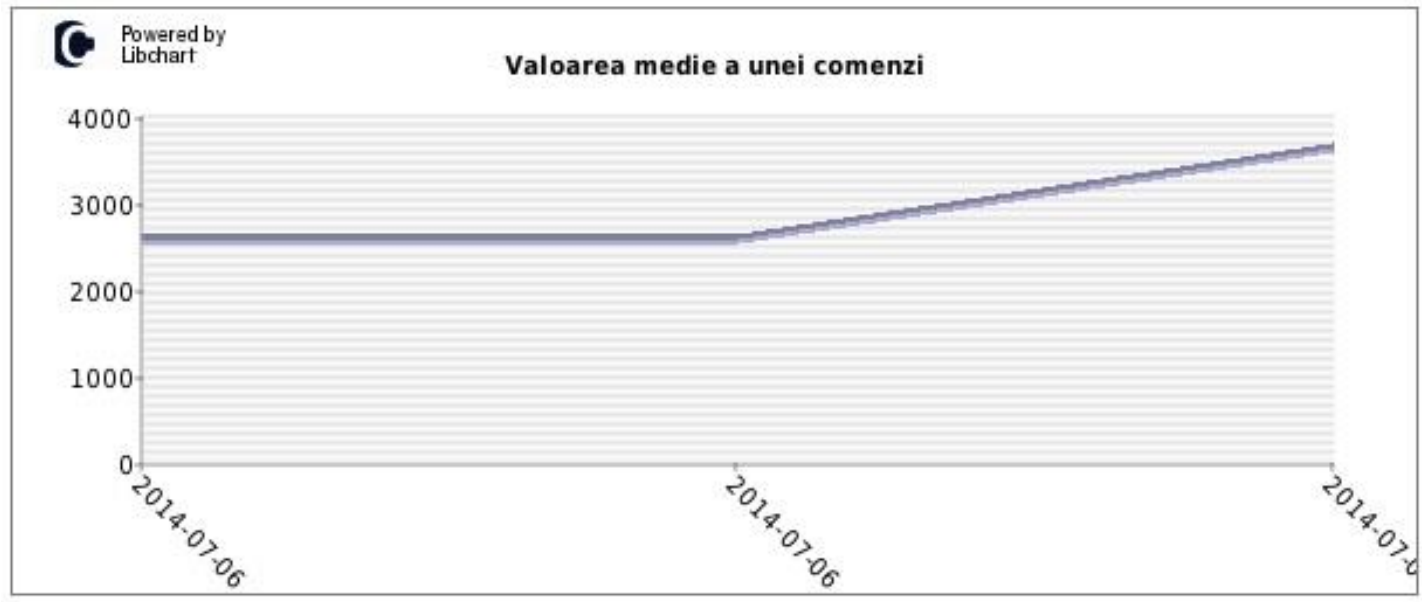

Fig. 8. Average value of an order (Valoarea medie a unei comenzi)

The collected data illustrates a positive change in this case, the value of each indicator has increased and the optimization was done through maximization. In conclusion, the final objective of increasing sales has been achieved through monitoring the three KPIs.

\section{Conclusions}

The scientific demarche was developed based on a literature review, in order to identify relevant aspects of an e-shop performance monitoring. Performance management systems based on KPIs are commonly used in large corporations, being also adopted by e-commerce businesses. The considered shopping cart performance management framework was successfully implemented, indicators like Orders conversion rate (Rata de conversie), Average products on an order (Numărul mediu de produse pe o comandă) and Average value of an order (Valoarea medie a unei comenzi) being monitored. The e-shop „ElectroShop" was put into operation, purchasing processes being recorded, indicators being calculated and their evolution over time analyzed. Thanks to the concrete implementation aspects, future extension of the model is possible. We intend to increase the set of indicators in order to provide a complete view of the e-commerce processes performance.

\section{References}


[1] A. Botezatu, Ce sunt indicatorii de performanţă, 2012, Available at : http://www.startups.ro/analize /ce-sunt-indicatorii-cheie-deperformanta

[2] R. Sharman, H. Raghav Rao, T.S. Raghu, (Eds.), Exploring the Grand Challenges for Next Generation E-Business: 8th Workshop on E-Business. Phoenix, AZ: Springer Science \& Business Media, 2011.

[3] M. Minoiu, Ce sunt KPI's?, 2011, Available at: http://www.exec-edu.ro/_articole/cesunt-kpi-s-f/

[4] F. J. Reh, Key Performance Indicators (KPI), 2014, Available at: http://management.about.com/cs/ generalmanagement/a/keyperfindic.htm

[5] W. Thomson, Popular Lectures and Addresses. London: Macmillan, 1891.

[6] A. R. Simon, S. L. Shaffer, Data warehousing \& Business intelligence for e-Commerce. San Francisco, CA: Morgan Kaufmann, 2001.
[7] Ensight Management Consulting, Utilizarea indicatorilor de măsurare a performanţei (KPI) în companiile din România, 2000, Available at: http://www.ensight.ro/wp-content/uploads/2010/12/Executive-summary-Studiu-KPI-RO.pdf [8] P. Sostre, J. LeClaire, Web Analytics For Dummies. Indianapolis, IN: Wiley Publishing, 2007.

[9] E.T. Peterson, The Big Book of Key Performance Indicators.Portland, OR: Web Analytics Demystified, 2006.

[10] *** - ProqSquad, Up-selling și Crossselling, 2011, Available at: http://progsquad.ro/blog/kb/tac-mainmenu/item/79-termeni-concepte-up-sellingcross-selling

[11] J. Chety, KPIs for an Online Retail Site, 2006, Available at: http://web-scapes.blogspot.ro/2006/08/kpis-for-online-retailsite.html

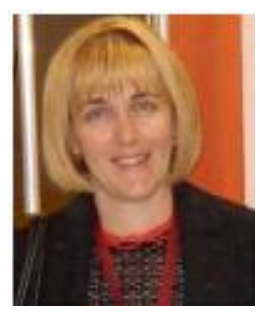

With a background in Computer Science and a Ph.D. obtained both in Technical Science and in Economic Science (Economic Informatics), professor Mihaela I. MUNTEAN focused her research activity on topics like information technology, knowledge management, business intelligence, business information systems. Over 70 papers in indexed reviews and conference proceedings and the involvement with success in 7 multi-annual national research grants/projects are sustaining her contributions in the research fields mentioned above. Currently, professor Mihaela I. Muntean is the chair of the Business Information Systems at the West University of Timişoara and an IT independent consultant.

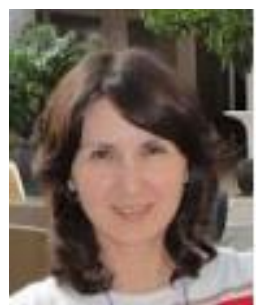

Diana TÂRNĂVEANU has graduated the Faculty of Mathematics, West University of Timişoara in 1995. She holds a PhD diploma in Management from 2008. Currently she is an associate professor within the Department of Business Information Systems at Faculty of Economics and Business Administration from the West University of Timişoara. Diana Târnăveanu's interests are in the fields of business intelligence, knowledge management, decision support systems. She is the author of more than 10 books and over 35 journal articles in the field of Knowledge Management, Decision Support Systems and Business Intelligence.

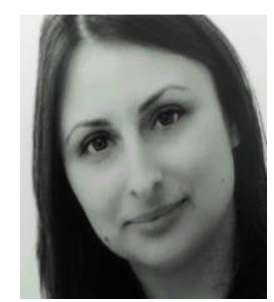

Alina ION graduated West University of Timişoara, Faculty of Economics and Business Administration, Economic Informatics Bachelor's Degree in 2009 and Business Information Systems's Master Degree in 2014. She currently works as Senior Research Platform Administrator at InSites Consulting Timişoara. 